\title{
School Inspection Practices - Evidence from Secondary Schools in Western Uganda
}

\author{
Jerry Bagaya (Corresponding author) \\ Makerere University, Uganda \\ E-mail: jbagaya@yahoo.co.uk \\ Betty Akullu Ezati \\ College of Education and External Studies, Makerere University, Uganda \\ Wycliffe Scot Wafula \\ College of Education and External Studies, Makerere University, Uganda \\ Palle Damkjær Rasmussen \\ Department of Learning and Philosophy, Aalborg University, Danmark
}

Received: January 5, 2020 Accepted: January 5, $2020 \quad$ Published: February 20, 2020

doi:10.5296/jet.v7i1.16181

URL: http://dx.doi.org/10.5296/jet.v7i1.16181

\begin{abstract}
The study examined inspection practices in secondary schools in Western Uganda. Towards achieving this objective, a Concurrent Triangulation Mixed Methods Design, involving questionnaire survey and interview, with a total of 399 participants in the categories of teachers, head teachers, school inspectors from 36 secondary schools in four districts of Western Uganda, was adopted. Quantitative data to test the resultant hypothesis were analysed using Chi Square Goodness of Fit Test while qualitative data were analysed using Qualitative Content Analysis. The study revealed that inspection practices in secondary schools were perceived as largely ineffective. The study concluded that despite the value attached to school inspection in the theoretical, political, and institutional and policy debates, inspectors continue to think and act according to the traditional notions of school inspection as evidenced by practices hinged on control. The major implication of the study is that understanding the practices before, during and after school inspection will allow policy makers, inspectors, teachers and headteachers to design better practices and benefit from them. The study also proposes a theoretical model for effective school inspection that requires further research and measurement to determine its validity so that lessons can be learnt that can assist inspectors in the future.
\end{abstract}

Keywords: Inspection, inspection practices, Secondary schools, Uganda 


\section{Introduction}

School inspection in Uganda is a legacy of the colonial rule that has undergone several transformations from the 1920s to date. Major social, economic and political developments in the $20^{\text {th }}$ and $21^{\text {st }}$ century have influenced the nature of Ugandan education system. More stakeholder involvement, massification of education, international commitments, and employer expectations have made schools more open to public scrutiny demanding accountability and quality education (Ministry of Education and Sports (MoES), 2017; National Planning Authority, 2010; Republic of Uganda, 2013; United Nations, 2015a; Wilcox, 2000). The changes in the teaching profession as a result of globalisation, demand innovation on the part of teachers to be able to manage uncertainties in the education environment. Consequently, support services like inspection to improve the effectiveness of teaching have become a focus for many countries, which has seen the inspection system restructured to ensure quality education service provision (Ali, 1998; Education Standards Agency, 2006a; Government of the Republic of Uganda, 1992; Lugujjo, 2008; Ministry of Education and Sports (MoES), 2000, 2017, Ministry of Education and Sports, 2004, 2008; Winkler, Sondergaard, Nannyonjo, Habyarimana, \& Shkaratan, 2008).

In July 2001, Education Standards Agency (ESA) in Uganda was set up as a semi-autonomous body beginning with a thin staff at the headquarters, following the recommendations made in the Policy Review Report of 1989 and adopted in the Government White Paper on Education of 1992 to replace the central inspectorate. It was envisaged that as a semi-autonomous agency, "ESA would be responsible for its own plans, programme and priority setting" (Ward, Penny, \& Read, 2006; p.85). This was in line with observation that successful public service regulation requires that a regulatory agency should be independent (Casteel \& Roebuck, 2000). But in fact, the ESA did not operate as a semi-autonomous body. In 2004, four regional offices were set up in Gulu, Mbale, Mpigi and Mbarara, each with 12 subject specialists. Key among reforms initiated by ESA was the development, testing and refinement of quality indicators comprising of three components: Inputs (leadership and management), processes (pedagogy), and outcomes (learners' achievement) (Education Standards Agency, 2006; Ministry of Education and Sports, 2012). In addition, inspection procedures and instruments were developed (Education Standards Agency, 2006).

The enactment of the Education Act (2008) to replace the Education Act (1970) formally abandoned the semi-autonomous status of ESA and recognised it as a directorate in MoES thereby renamed it the Directorate of Education Standards (DES) with the mandate of maintaining qualitative academic and disciplinary standards in the education sector and institutions in Uganda. The Education (Pre-Primary, Primary and Post-Primary) Act (2008) gave inspectors powers to enter any school with or without notice.

Under the new structure, the Director headed the headquarters while an Assistant Commissioner Education Standards, who directly supervised 12 specialist Senior Inspectors, headed the regions. The new structure, therefore, was a paradigm shift from general inspection to subject teacher inspection in the hope of enhancing the quality of teaching and consequently raising achievement standards of learners in secondary schools. 
In Uganda, the secondary school level is one of the most critical levels in the education system because it prepares learners for advanced skills training in post-secondary institutions. To that end, therefore, any attempt to improve quality of secondary schools, especially through school inspection should be given the attention it deserves. The inspection system, however, has continued to be administrative and largely non-academic in character. Given the many different tasks bestowed upon inspectors amidst inadequate resources, there is a tendency to give more time to administrative tasks at the expense of pedagogical issues. Failure to strike a balance between the control and support function has been of concern since the inception of the inspection system in the world (IIEP-UNESCO, 2007). Consequently, there was a need to investigate the nature of inspection practices and suggest an effective inspection model.

The study is envisaged to benefit society, inspectors, teachers, researchers, policy makers and administrators by creating awareness of the available inspection services, providing a basis for policy review, and adding to the limited literature, in Uganda, on inspection practices. The study also proposes an inspection model that may help in restructuring the inspection system.

\section{Review of Related Literature}

\subsection{Habermas' Theory of Communicative Action}

This study drew on the Theory of Communicative Action (TCA) advanced by Jürgen Habermas. TCA presupposes the use of language as a medium of reaching a common understanding through empirical rationality and verification. The theory postulates that: "Actors in society seek to reach a common understanding and to coordinate actions by reasoned argument, consensus and cooperation rather than strategic action strictly in pursuit of their own goals" (Habermas, 1984:86). The theory emphasises widespread participation by all stakeholders, with a practical attitude, and reaching consensus on the plan of action through stakeholder dialogue where all partners deliberately refrain from exercising their power resources (Bolton, 2005; Mitrović, 1999). TCA distinguishes between two types of human action based on different rationalities: strategic action and communicative action. Strategic action coordinates interaction by force or influence while communicative action coordinates social interaction via dialogue and consent (Habermas, 1984; Habermas \& McCarthy, 1987)

As applied to this study, TCA holds that inspectors can only be considered as change agents when their interactions with stakeholders are coordinated through a medium of language and practical discourse on a plan of action for improvement; thereby modifying the way stakeholders think and act. In organizing inspection, the MoES and the ESA should take pains to establish fora where this kind of coordination can take place. In this way, the theory makes a contribution to a better understanding of how inspection works to induce change in schools.

\subsection{Inspection Practices}

Existing research and literature reveal that countries with effective inspection systems have systematically laid down procedures for carrying out inspection activities. For example, Inspectors are expected to consult previous inspection reports and decide on which schools to 
inspect and the type and focus of inspection prior to inspection (Education Standards Agency, 2006a; Mohanty, 2000; Singhal, Bhagia, Kalpande, \& Nair, 1986). Plans are also guided by specification of the number of schools to be inspected, the frequency and duration of inspection (Carron, De Grauwe, \& Govinda, 1998).

A study by de Grauwe (2001) in Tanzania, Namibia, Botswana and Zimbabwe revealed that inspectors make own plans annually but due to lack of resources, the plans are not fully implemented and the criterion of how schools are selected is not precisely detailed. The present study sought to determine whether inspection is implemented as stipulated in Education Standards Agency (2006a) given a dearth of studies evaluating the effectiveness of inspection practices in Uganda. In a more recent study in junior and secondary schools in Botswana on the nature of instructional supervision in schools, Moswela (2010) revealed that teachers were not involved in the supervision process. Although the study addressed the objective of the current study, it considered supervision by headteachers and not inspectors. In addition, the study used qualitative methods as opposed to the current study that used a mixed method design to gain greater insight into the pre-inspection practices.

Existing research generally indicates that pre-inspection practices feed into on-site inspection practices involving team inspection assignments and gathering evidence through observation of lessons, interviews, document analysis and questionnaires, providing feedback to individual subject teachers and final team meeting to arrive at corporate judgement about the school (Singhal et al., 1986; Wilcox, 2000). Towards the end of inspection, inspectors are expected to brief all stakeholders. Ofsted (2017) states that stakeholders must receive clear, unequivocal feedback on the effectiveness of the school at the end of the inspection. A draft report is sent to the school for checking and comments before a final report is completed and dispatched. Action plan should be sent to inspectors for follow-up purposes (Casteel \& Roebuck, 2000; Fergusson, 1998; Mohanty, 2000; Ofsted, 2013b, 2013a). In addition, many countries have put in place modalities for evaluating the work of inspectors and therefore their services. For example, the work of inspectors is monitored and assessed against set standards for quality of judgements, evidence, communication and conduct (Ofsted, 2013b, 2013a; Wilcox, 2000). In Botswana, Tanzania, Zimbabwe and Namibia, inspectors are assessed mainly on the quantity of the work done (de Grauwe, 2001). Mention, however, is not made of client satisfaction and their perceptions of the quality of inspection. It is not yet known whether evaluation of individual inspectors in Uganda is done following this criterion. And if it is done, it is not clear how this translates into evaluation of inspection in Ugandan secondary schools. The present study sought to establish whether the Ugandan inspection system followed the laid down procedures as pointed out in national and international literature.

A literature study by Ahmad, Said, Khan, and Ali (2013) revealed that lack of follow up, negative attitude of inspectors, political influence, workload, poor planning and bureaucratic tendencies as the major hurdles to the effectiveness of school inspection in Pakistan. The study recommended a thorough research study to explore the current practices and procedures of school inspection system. This study was a response to this call, not in the context of Pakistan, but in the Ugandan context. 
Aleesha (2012) studied the structure of inspection system in India, using interviews and document analysis, with a view to bringing out the major flaws that hinder it from accomplishing its objectives. Aleesha found that inspectors were burdened with administrative tasks leaving less time for pedagogical inspections, inspection reports were inadequately used in policy making, parents' views were not taken into account in assessing schools, and that reports were not published to the public. Aleesha's study compared the inspection system in India to that of the United Kingdom to reveal flaws. The current study, however, compares the inspection practices in Ugandan secondary schools to the established framework for the Ugandan inspection system. Similarly, Essaoudi, Lotfi, Talbi, and Radid (2015), while analysing the professional practices of Inspectors of Education and Training in Morocco, found that the tasks of inspectors were predominantly routine, administrative and relatively short. Relatedly, Haris, Naway, Pulukadang, Takeshita, and Ancho (2018), in a literature review study of school supervision practices in the Indonesian Education System, found that the supervisory role focused mainly on administrative rather than quality issues and was mainly influenced by inadequate resources, unrewarding career path, and the perception of inspection process as a compliance activity. In contrast to these results, Manase and Habibu (2017) found that $90 \%$ of respondents indicated that inspection items focused on pedagogy while only $10 \%$ focused on non-pedagogical issues in Tanzania.

Studying the factors that have led to the rapid rise of inspection as a governance mechanism in England, the Netherlands and Germany, Brown, McNamara, O'Hara, and O'Brien (2016), using document analysis, concluded that inspection has moved away from merely compliance to rules to creating an environment in which schools become more autonomous but being responsible for student achievement. According to Brown et al. (2016), this is done by ensuring quality, improvement, accountability, transparency, and cost effectiveness amidst scarcity of resources. The current study sought to establish whether the changing landscape of the school inspection system in England, the Netherlands and Germany applies to Uganda and therefore is in tandem with new public management philosophies.

In discussing the methodology of school inspection, Ehren (2016) posits that effective inspection requires that all stakeholders are involved in monitoring the implementation of inspection recommendations but on condition that they are convinced about the validity of the recommendations. In line with this, a study of stakeholder involvement in schools in Nakuru Municipality, Kenya, Gichohi (2015) found that participants perceived that stakeholder involvement influenced school performance to a great extent. The study, however, was conducted in primary schools while the present study was in secondary schools with a slightly different management structure.

The importance of stakeholder involvement in the inspection process is confirmed by a number of other scholars (Haris et al., 2018; Hooge, Burns, \& Wilkoszewski, 2012; Manase \& Habibu, 2017; Mokoena, 2011; Pradhan et al., 2012). For example, Haris et al. (2018) in a review of related literature revealed that effective supervision develops cooperation between schools and all stakeholders for school quality improvement initiatives. Hooge et al. (2012) indicated that school inspection can be complemented by other forms of accountability mechanisms involving key stakeholders, thereby taking the voices of a diverse set of 
stakeholders into account that will ultimately help to improve the quality of education. Manase and Habibu (2017) proposed involvement of various stakeholders - working together to ensure efficient and effective school inspection. In a qualitative inquiry investigating the extent to which rural schools understand, perceive and implement participative decision making in South Africa, Mokoena (2011) posits that participative decision making, though difficult to achieve, is a critical element in school system requiring creation of space for debate and dialogue for all stakeholders to participate sufficiently. Pradhan et al. (2012), in a study on improving education quality in Indonesia through enhancing community participation, revealed that the most important factor to improved student learning is the broader involvement of education stakeholders outside the school. The reviewed literature underscores the value of involving all stakeholders in nearly all school processes. It is important, therefore, to establish the extent of involvement of stakeholders in the inspection process in Uganda.

\section{Research Methodology}

The research was positioned within the pragmatism paradigm which assumes that there are multiple realities, many different ways of interpreting the world and therefore understanding research (Guba \& Lincoln, 1994; Hammond, 2013; Kalolo, 2015; Kivunja \& Kuyini, 2017; Saunders, Lewis, \& Thornhill, 2007; Shannon-Baker, 2016; Teddlie \& Tashakkori, 2015). In order to more effectively examine the issue under investigation, the Concurrent Triangulation Mixed Methods Design was adopted in which both qualitative and quantitative approaches were used for the purpose of breadth, depth of understanding and corroboration (Creswell, 2009; Wiersma \& Jurs, 2005). This design in which similar data was collected at a point in time from more than one population, was used because it is cost effective, allows for rapid data collection and its results can be generalised to a larger population (Cohen, Manion, \& Morrison, 2007).

The study targeted a population of 42 inspectors, 337 headteachers and deputy headteachers, and 6372 teachers in all the secondary schools in Western Uganda (Ministry of Education and Sports [MoES], 2013). The sample for the quantitative component consisted of 429 respondents including 24 inspectors, 36 headteachers and 36 deputy headteachers, and 333 teachers from 36 secondary schools in Buliisa, Masindi, Kasese and Kyenjojo districts of Western Uganda. Cochran's formula was used to determine the appropriate sample size (Cochran, 1977). The researcher used purposive sampling to select the region and districts, stratified random sampling to select the schools and simple random sampling to select the supervisors and teachers. Data were collected using Likert scale questionnaire and interview guide.

Establishing Content Validity Index (CVI) of the instruments ensured quality of the data. The scale CVI values of 0.903 and 1.00 for the questionnaire and interview guide respectively, computed by the S-CVI/Ave method were all above the acceptable threshold of 0.70 (Amin, 2005 ) and therefore were considered to have high content validity. A pilot test was conducted and Cronbach's Alpha computed was 0.919 and statistically significant beyond $p<0.05$, indicating relatively high and acceptable level of internal consistency. 
Data were summarised using frequencies and ratios, to look for emerging trends and patterns. The resultant hypothesis was tested using the Chi square Goodness of Fit Test (Amin, 2005; Balnaves \& Caputi, 2001). Qualitative Content Analysis (QCA) involving systematic coding of text data to allow researchers understand social reality from the original meanings expressed by the key informants was used to analyse the qualitative data (Miles \& Huberman, 1994; Saldana, 2009).

\section{Results/Findings}

Descriptive statistics in Table 1 show the frequency table of the cross-tabulation of each of the 24 questionnaire items on inspection practices and the relevant response rating scale. Column 7 of Table 1 represents the ratio that is used to establish which of the questionnaire items were more positively or negatively perceived.

Ratios in column 7 of Table 1 show that items relating to notice of inspection, debriefing meetings, alignment of inspection to school timetables, duration of inspection, duration of lesson observation, matching of inspection to subject speciality, expeditious issuance of reports, and handling of complaints were substantially more negatively viewed by the respondents. The more positively perceived items concerned use of a variety of data collection methods, post-observation conferencing, provision of feedback to teachers observed, corporate judgement, fairness of reporting, action planning, follow-up inspection, and evaluation of inspection services. In addition, advance request for school documentation, matching expertise to teacher needs, frequency of inspection and dissemination of supervision findings were relatively positively perceived. Overall, $16(66.7 \%)$ items were positively perceived compared to eight (33.3\%) negatively perceived items of the inspection practice subscale. This suggests that inspection practices in secondary schools in Western Uganda were relatively supportive.

The Chi Square Goodness of Fit Test was used to determine whether the inspection practices, categorised as non-supportive practices and supportive practices, were equally perceived.

Table 2 provides the actual results of the Chi Square Goodness of Fit Test. We can see from the table that our test statistic is not statistically significant, $\chi^{2}(1, n=377)=.448, p=0.503>0.05$. Therefore, we do not reject the null hypothesis and conclude that there is no statistically significant difference in the perception of the respondents of inspection practices in the population from which the sample of 377 respondents was drawn. Therefore, the majority of respondents perceived inspection practices as more supportive $(51.7 \%)$ than those who perceived them as non-supportive $(48.3 \%)$.

To further explore the variable and provide more comprehensive analysis of inspection practices, data were collected using the qualitative approach in which six teachers, 13 headteachers and three inspectors were interviewed. Participants were asked to describe the extent to which teachers were involved in planning of inspection activities, the activities inspectors engaged in, and how inspectors reported their findings. The findings from the interviews are presented next. Quotes from participants are used to further illuminate the findings. 
Table 1. One-way Frequency for Perceptions of Inspection Practices

\begin{tabular}{|c|c|c|c|c|c|c|}
\hline Item & SD & D & UD & $\mathbf{A}$ & $\mathbf{S A}$ & Ratio \\
\hline $\begin{array}{l}\text { Planning of secondary school inspection involves } \\
\text { inspectors, headteachers, and teachers. }\end{array}$ & 49 & 53 & 27 & 155 & 93 & 0.411 \\
\hline $\begin{array}{l}\text { Inspectors consult previous inspection reports in } \\
\text { preparation for inspection. }\end{array}$ & 32 & 67 & 57 & 172 & 49 & 0.448 \\
\hline $\begin{array}{l}\text { At least one-month notice of inspection is given to } \\
\text { schools in preparation for inspection. }\end{array}$ & 127 & 113 & 45 & 74 & 18 & 2.609 \\
\hline $\begin{array}{l}\text { Prior to inspection, headteachers and teachers are } \\
\text { briefed on the purpose, methods and outcomes of the } \\
\text { inspection. }\end{array}$ & 94 & 110 & 60 & 89 & 24 & 1.805 \\
\hline $\begin{array}{l}\text { School documentations are requested in advance for } \\
\text { inspection. }\end{array}$ & 55 & 93 & 44 & 137 & 48 & 0.800 \\
\hline $\begin{array}{l}\text { The expertise of the inspection team is matched to } \\
\text { the needs of teachers in a given school. }\end{array}$ & 35 & 96 & 61 & 162 & 23 & 0.708 \\
\hline DES inspectors spend at least two days in a school. & 150 & 133 & 55 & 33 & 6 & 7.256 \\
\hline Each school is inspected at least once a term. & 58 & 101 & 46 & 142 & 30 & 0.924 \\
\hline $\begin{array}{l}\text { DES inspectors observe the entire period of the } \\
\text { lesson. }\end{array}$ & 59 & 120 & 57 & 123 & 18 & 1.270 \\
\hline Inspectors align their activities to school timetables. & 76 & 100 & 57 & 120 & 24 & 1.222 \\
\hline $\begin{array}{l}\text { Inspectors use a variety of information gathering } \\
\text { methods }\end{array}$ & 24 & 45 & 51 & 177 & 80 & 0.268 \\
\hline $\begin{array}{l}\text { Inspectors only observe lessons for subjects of their } \\
\text { speciality. }\end{array}$ & 123 & 158 & 47 & 32 & 17 & 5.735 \\
\hline $\begin{array}{l}\text { Inspectors hold post-observation conference with all } \\
\text { teachers that were observed teaching. }\end{array}$ & 41 & 59 & 38 & 187 & 52 & 0.418 \\
\hline $\begin{array}{l}\text { Inspectors provide immediate feedback to teachers } \\
\text { following lesson observations. }\end{array}$ & 43 & 81 & 36 & 161 & 56 & 0.571 \\
\hline $\begin{array}{l}\text { Inspectors hold team meetings to arrive at corporate } \\
\text { judgement about the quality of school services. }\end{array}$ & 31 & 82 & 80 & 155 & 29 & 0.614 \\
\hline $\begin{array}{l}\text { Inspection findings are shared with staff, members } \\
\text { of the Board of Governors and all other } \\
\text { stakeholders. }\end{array}$ & 45 & 110 & 55 & 134 & 33 & 0.928 \\
\hline $\begin{array}{l}\text { Detailed reports are within issued two weeks of } \\
\text { inspection. }\end{array}$ & 74 & 138 & 93 & 63 & 9 & 2.944 \\
\hline $\begin{array}{l}\text { The final written inspection report is a fair reflection } \\
\text { of the informal feedback received. }\end{array}$ & 21 & 59 & 87 & 184 & 26 & 0.381 \\
\hline $\begin{array}{l}\text { All responsible stakeholders develop action plans to } \\
\text { address key action points in inspection reports. }\end{array}$ & 43 & 63 & 56 & 172 & 43 & 0.493 \\
\hline $\begin{array}{l}\text { Action plans to address areas in need of } \\
\text { improvement are sent to the DES and to the parents. }\end{array}$ & 27 & 62 & 67 & 192 & 29 & 0.403 \\
\hline $\begin{array}{l}\text { DES makes follow up inspections at least once a } \\
\text { year. }\end{array}$ & 35 & 79 & 72 & 161 & 30 & 0.597 \\
\hline
\end{tabular}




\begin{tabular}{|l|r|r|r|r|r|r|}
\hline \multicolumn{1}{|c|}{ Item } & SD & D & UD & A & SA & Ratio \\
\hline $\begin{array}{l}\text { Inspection in Uganda is evaluated at least once in a } \\
\text { year. }\end{array}$ & 22 & 46 & 120 & 159 & 30 & 0.360 \\
\hline $\begin{array}{l}\text { Evaluation of inspection involves inspectors, } \\
\text { headteachers and teachers. }\end{array}$ & 42 & 75 & 64 & 152 & 44 & 0.597 \\
\hline $\begin{array}{l}\text { DES has a complaints desk for people who are } \\
\text { dissatisfied with some aspects of inspection. }\end{array}$ & 56 & 117 & 121 & 68 & 15 & 2.084 \\
\hline
\end{tabular}

Table 2. Perception of Supervision Practices

\begin{tabular}{|c|c|c|}
\hline \multirow{2}{*}{ Frequency } & \multicolumn{2}{|c|}{ Inspection Practices } \\
\cline { 2 - 3 } & Supportive Practices & Non-Supportive Practices \\
\hline Observed & $195(51.7 \%)$ & $182(48.3 \%)$ \\
\hline Expected & 188.5 & 188.5 \\
\hline \multicolumn{2}{|c|}{$\chi^{2}=0.448, d f=1, p=0.503>0.05$} \\
\hline
\end{tabular}

The first interview question was "To what extent do inspectors involve stakeholders in planning of inspection?" The participants' comments revealed a common view on the extent of involvement of stakeholders in planning of inspection. According to all the participants, inspectors did not involve stakeholders in preparing for inspection. Serious comments on the non-involvement of stakeholders were common as revealed by one teacher:

... they come abruptly; there is no time that they are coming on this day. So, they find when you do not have what to provide to them on their checklist. So, it is a big challenge. It makes you run around.

One headteacher, highlighting the inadequacy of planning of inspection put it that:

... the perception of inspectors is that they should get you unprepared. It is like they are faultfinders. So, the teachers are never involved at all; very limited extent. Inspectors are supposed to just fall in any time -take everybody by surprise. It is like fault finding, not corrective.

Confirming what the teacher and headteacher said, one inspector added: “... we plan on our side and we just go to visit schools depending on the purpose of inspection and so we rarely involve them in the planning." This narrative also suggests that inspection is mostly through surprise visits.

The second interview question was: "What activities do inspectors engage in when they visit secondary schools?" The majority of participants perceived inspection as focusing more on administrative than pedagogical issues. Participants identified activities carried out by DES to include checking schemes of work, examination of documents, inspection of facilities, and meeting some stakeholders, which activities are largely administrative. As this headteacher expressed in describing inspection activities that:

... in most cases they stop at the administration level-offices. And then they start asking for information about finances, whether you have audit reports; they ask you to 
what extent you have been able to comply with the basic requirements and minimum standards, the general administration of the school.

Another headteacher added:

... they look at first of all schemes of work. From there they move to other areas like probably the laboratories; how effectively we are utilising the laboratories in the development of sciences. They move around may be to look at stores ... They go to the staffroom and probably look around the school environment. That is at least the farthest they have gone. They have not gone physically in class to see how the teaching is progressing.

Such experiences as described by headteachers were confirmed by one teacher: “... they first reach the office, they pass through the school, they ask about USE ... and try to analyse whether we make everyday records on class and school performance." Like the teacher and headteacher, the inspectors' comments had very little mention of inspectors engaging in lesson observation and conferencing with teachers with a view to improving pedagogy in schools: " ... after briefing the administration, then there is administration of the tool depending on the areas of interest - there is examination of records, there is inspection of facilities."

The third interview question was: "How do inspectors report their inspection findings?" The majority of participants revealed that reporting of inspection findings was mainly at administration level with very limited involvement of teachers and almost no involvement of other stakeholders like students, parents and Board of Governors. This assertion is evident in the following comments by one teacher:

“... the report they would write we would not see what would be given because they would write and leave it in the office. So, feedback issue. Although for them they leave feedback, the administration may put it in the file and keep it."

Other teachers added: "First, there are findings that they make and leave with us. Then, they make a report and send to us at a later time." "They are supposed to meet the administrators first. Then after that the administrators call a meeting to teach us." and "After inspecting, they always come and inform as to whether we are doing well or not."

Confirming teachers' perceptions, one headteacher added that: “... after making their judgement, they do sign and hand over the copy of the report which is kept in the school inspection file. They go with the originals". Another headteacher indicated that:

But most of the time these inspectors when they come, you find of course they first visit the headteacher then they go. They assume that once they talk to the headteacher, then the headteacher will communicate to the teachers on the minimum standards.

The study findings reveal that inspectors mainly use surprise visits with no involvement of teachers in planning of inspection. They focused more on administrative roles than pedagogical roles, while reporting of findings was mainly at administrative level with little involvement of other key stakeholders. 


\section{Discussions}

The study revealed that inspectors were not giving schools sufficient notice of inspection and therefore tended to predominantly use surprise visits without involvement of the schools in the planning of inspection. This finding confirms observation by some scholars (Aleesha, 2012; Hossain, 2017; Tanah, 2011; Wilcox, 2000) that in the majority of inspections, schools were neither informed nor involved in the planning of inspection. Thus, the Ugandan school inspection system can be considered as lacking in participatory planning, tending to catch schools unawares by not providing advance notice and therefore likely to be counterproductive. This modality may result in schools resenting inspection by labelling it a fault-finding mission; in addition to creating fear, panic and sense of insecurity among teachers. The finding, however, is at variance with international literature discussed in Section 2.2 above, which indicates that effective inspection always involves stakeholders before, during and after inspection. The lack of involvement of schools in the planning of inspection services could be attributed to the lack of a mandatory provision in the Handbook for School Inspectors (Education Standards Agency, 2006). Furthermore, inspectors may have lacked the necessary training in modern inspection approaches. The researchers argue that the way in which teachers or schools are prepared for inspection will affect the quality of changes brought about by the inspection process. Mental preparation for the inspection is vital.In this study, we argue that the practice of unannounced inspection can stir up mistrust among teachers towards the inspectors. Where there is mistrust, efforts to develop a robust quality assurance culture in secondary schools are likely to be inhibited. Once teachers perceive inspection as a form of policing, compliance issues are likely to arise. In addition, increased uncertainty about when the school will be inspected may result in schools focusing more on the inspection process at the expense of school pedagogy. To, therefore, build good rapport, increase interaction with well-prepared teachers, and have more efficient use of both the inspectors' and teachers' time, a notice of inspection is important. Perhaps what remains to be established is the appropriate time between notification and the inspection that will not put too much pressure on schools to prepare for the inspection but allow them enough time to collate the documentation needed for inspection and align school programmes with the inspection schedule.

The study also revealed that teachers and headteachers, in addition to not receiving advance notice of an impending inspection, were not adequately debriefed. Consequently, school schedules were affected when staff was called upon to look up specific information demanded by the inspectors. This was likely to impact negatively on the smooth functioning of the school system during the inspection period. This finding is consistent with the finding of Scanlon (2001), which revealed that inspection resulted in increased workload and stress and Penninckx et al. ( 2015) who found that inspection increased stress, anxiety, tiredness and window dressing. The finding, however, contradicts the fieldwork procedures as set out in the Handbook for School Inspectors (Education Standards Agency, 2006), which requires inspectors, upon arrival, to introduce themselves, explain the purpose of the visit, discuss the inspection plan, list documents that will be required (if not requested in advance notice), sample classes to be visited, book interviews with stakeholders in advance; so as to set a productive tone for the inspection. These findings, in the context of TCA, supports the need 
for organizing inspection in a way that allows and emphasizes communication with the aim of reaching a common understanding of process and outcomes.

The study further revealed that headteachers, teachers and inspectors were not satisfied with the duration of inspection. Irrespective of the type of inspection, inspectors in the Ugandan secondary schools did not spend more than eight hours in a given school; and therefore, were unable to contribute to meaningful improvement that reached the level of teaching practice and student learning. Given the short duration of inspection, inspectors were reportedly concentrating more on administrative duties at the expense of pedagogical duties; which demand more time and effort. This finding is in tandem with other studies (Ahmad et al., 2013; Carron \& De Grauwe, 1997; Essaoudi et al., 2015; Hossain, 2017; Ige, 2012), which found out that the average time spent on visits by inspectors was inadequate given the complexity of school systems. The finding, however, contradicts national and international standards that recommend that for inspection to be effective, the duration of inspection should be at least two to five days (Brown et al., 2016; Hossain, 2017; Ige, 2012). The most likely reasons for the short duration of inspection in Uganda are the expanding size of the education system without proportionate increase in the number of inspectors, inadequate funding and/or facilitation to the inspectors.

Another finding of the study was that inspectors carried out general inspection as opposed to subject-based inspection despite the fact that the majority of inspectors were subject specialists. A question therefore arises as to whether these inspectors have the expertise to improve each teacher's pedagogical practice. This practice contradicts Panigrahi's (2012) finding that indicated "... instructional supervision is constrained by the subject specialisation of the supervisor.” (Pg. 60). Since an inspector's specialisation is restricted to one or two subjects of the curriculum, is it in order and/or sustainable for inspectors to only inspect and guide teachers in their areas of specialisation? We argue that inspectors should have and use both general and discipline-specific competences. Inspectors can still offer general guidance to teachers in other disciplines. It is not feasible for DES to have subject specialists in every secondary school curriculum area. Otherwise exclusive use of specialists may create additional costs and slow down the inspection process. Although specialists are superior to generalists in a specific subject area, a generalist has broad knowledge in all curriculum areas but with expertise in pedagogy and is therefore capable of supervising and inspecting teachers of all subjects. What is needed is time and funding to plan and conduct inspection as well as high quality continuous professional development for the inspectors.

The study further revealed that inspectors did not expeditiously provide reports to the schools and when provided, the reports were not readily accessible to the staff and parents but were mainly seen by the administrators. For teachers whose lessons were observed, however, opportunities were provided for conferencing. This finding agrees with Gray (2014) who observed that reports produced are normally not accessed by the general public and teachers. This finding, however, is contrary to the provisions of the Handbook for School Inspectors (Education Standards Agency, 2006); that requires timely dissemination of the inspection reports to all key stakeholders if the findings are to be current and relevant to stimulate action for improvement (Council of the Inspectors General on Integrity and Efficiency, 2012). The 
basic assumption is that this kind of dissemination enables the public to hold schools accountable and therefore enhance school improvement (Gray, 2014; Janssens, 2011). Research also shows that dissemination of inspection findings to all stakeholders demands quality processes for the inspectors (Janssens, 2011). In publishing reports, therefore, inspectors should strike a balance between respect of the rights of individual staff to privacy on the one hand, and the right of the general public to information concerning the efficiency and effectiveness of schools. This means that for published reports, the names of individual staff should not be included (Gray, 2014). It is important that inspection reports are accessible, complete and timely if inspection is to be viewed in a positive light; in addition to creating an inbuilt incentive for school authorities to improve the services they are providing.

On the positive note, the study revealed that inspectors used a variety of data collection methods including interviews, document analysis, observation of lessons, in agreement with the provisions of the Handbook for School Inspectors (Education Standards Agency, 2006) and Council of the Inspectors General on Integrity and Efficiency (2012), which require information to be sufficiently reliable and valid to inform bias free judgements, conclusions and recommendations. According to Ofsted (2017), the use of various methods of data collection increases confidence in the results produced as a result of confirmation through convergence of different perspectives and for completeness. As a result, stakeholders are more likely to accept the findings, conclusions and recommendations arising from such a process. In addition, triangulation of data collection methods increases inspectors' in-depth understanding of the context in which the schools are operating and provide appropriate guidance and recommendations that are acceptable to everybody.

Where more than one inspector inspected a school, the study revealed that the inspection team corporately arrived at judgements about the quality of the education service provided by the schools, and provided immediate feedback to teachers whose lessons were observed. This is in line with standard operating procedures that require that inspection reports should state concisely what was found in terms of strengths and weaknesses, and what should be changed to remedy the situation and that at the end of the inspection, the key stakeholders should be given a short verbal feedback on the results of the inspection (Education Standards Agency, 2006; Ofsted, 2013b, 2013a, 2017). However, questions are raised on the quality of the feedback and the extent to which teachers can use the feedback to improve teaching practices. For example, is feedback that highlights strengths, weaknesses and recommendations meaningful? With the current practice where the duration of inspection is very short, do inspectors allow time for more interactive and effective feedback sessions?

On action planning and follow-up on implementation of inspection recommendations, the study revealed that, although inspectors made follow up visits, these visits were watered down by non-involvement of stakeholders in both the action planning process and follow-up. This finding contradicts the available literature that requires that in making follow up visits, inspectors should engage all key stakeholders in evaluating the progress the school has made in implementing inspection recommendations and advising on strategies and actions to enable the schools to fully address the recommendations (Baxter, Hastings, Law, \& Glass, 2014; Ehren, 2016; Gichohi, 2015; Hooge et al., 2012; Manase \& Habibu, 2017; Wilcox, 2000). 
For inspection to be effective, the researchers argue that follow up visit should be conducted after a fair and reasonable time ( $1-2$ years), which allows schools to make progress in addressing the recommendations but should also be cognizant of the nature of recommendations and the context of the school. It is important to note that improvement through inspection can only be gauged from the extent to which the recommendations are implemented (Ehren, 2016).

These findings, in the context of Habermas Theory of Communicative Action, tend to support the assertion that inspection can only be effective where authority, tradition or force is put aside to allow the unfolding of reason - resolving issues through argument and discussion of matters of public concern or common interest. TCA in the context of school inspection, therefore, aims at respecting teachers' values and not to impose solutions. In so doing, teacher creativity and consequently student achievement is likely to be enhanced. The core of the school is the view that learning and development as a process takes place between people in dialogue through reflection and discussion. Inspection is meant to help development, but not exercising control of the school activities. The inspectors should be involved in a dialogue with teachers, students and the community about teaching, educational content and quality in building consensus among all stakeholders. Inspection recommendations, therefore, in which all the stakeholders are creatively involved, are implemented to a higher degree than when participation is limited to listening to others' conclusions.

When applied to school improvement, communicative behaviour is characterised by dialogue in which stakeholders try to understand each other's perception of a phenomenon, as opposed to goal-rational behaviour in which supervisors define what perception will be valid, and what they want to achieve. The results of this study show that inspectors put considerable merit on goal-rational behaviour, while communicative behaviour tends to be underrated. It is argued, therefore, that rather than exclusively act as agents of control, inspectors should ease the process of teaching and learning by creating opportunities for teachers to reflect on their performance. Inspection should be a mutual influence process rather than a one-way relation. Inspection, therefore, should be about dialogues rather than monologues; where key stakeholders are included as equal and active members of the inspection process. To some extent, however, the inspectors will still have to be agents of control. Schools are part of the public education system and have a responsibility given by the political decision-makers and the public. In this context, a TCA approach to inspection implies that inspectors should explain and argue for the findings that they report to the MoES.

\section{Conclusions}

The researchers contend that inspectors continue to think and act according to the traditional notions of school inspection hinged on control and consequently the practice is perceived as ineffective. Inspectors' power seems to lie in taking administrative decisions but lack the authority to give pedagogical advice. Furthermore, the mandate of inspectors always outweighs by far the resources. Therefore, rather than continuously demanding more resources that may never come, inspectors should restrict their mandate to covering a limited number of schools especially those that need their intervention most. School inspection practices in Uganda, therefore, ought to be reconceptualised in relation to Habermas TCA, so 
as to move away from superficial to substantive school improvements.

\section{Implications of the Research}

First, the major implication of the study is that it contributes to the much-needed empirical data on practices of school inspectors in middle- and low-income countries. Understanding the activities before, during and after school inspection will allow policy makers, inspectors, teachers and headteachers to design initiatives based on the inspectors' actual practices. For example, inspectors could take note that teachers and headteachers of the schools that are inspected do not perceive the practice of surprise visits in a positive light. This will allow them to review the pre-inspection practices accordingly. Many other stakeholders could derive similar implications from the findings of the study.

Second, a theoretical model for effective school inspection (Figure 1) is proposed that requires further research and measurement to determine its validity so that lessons can be learnt that can assist inspectors in the future.

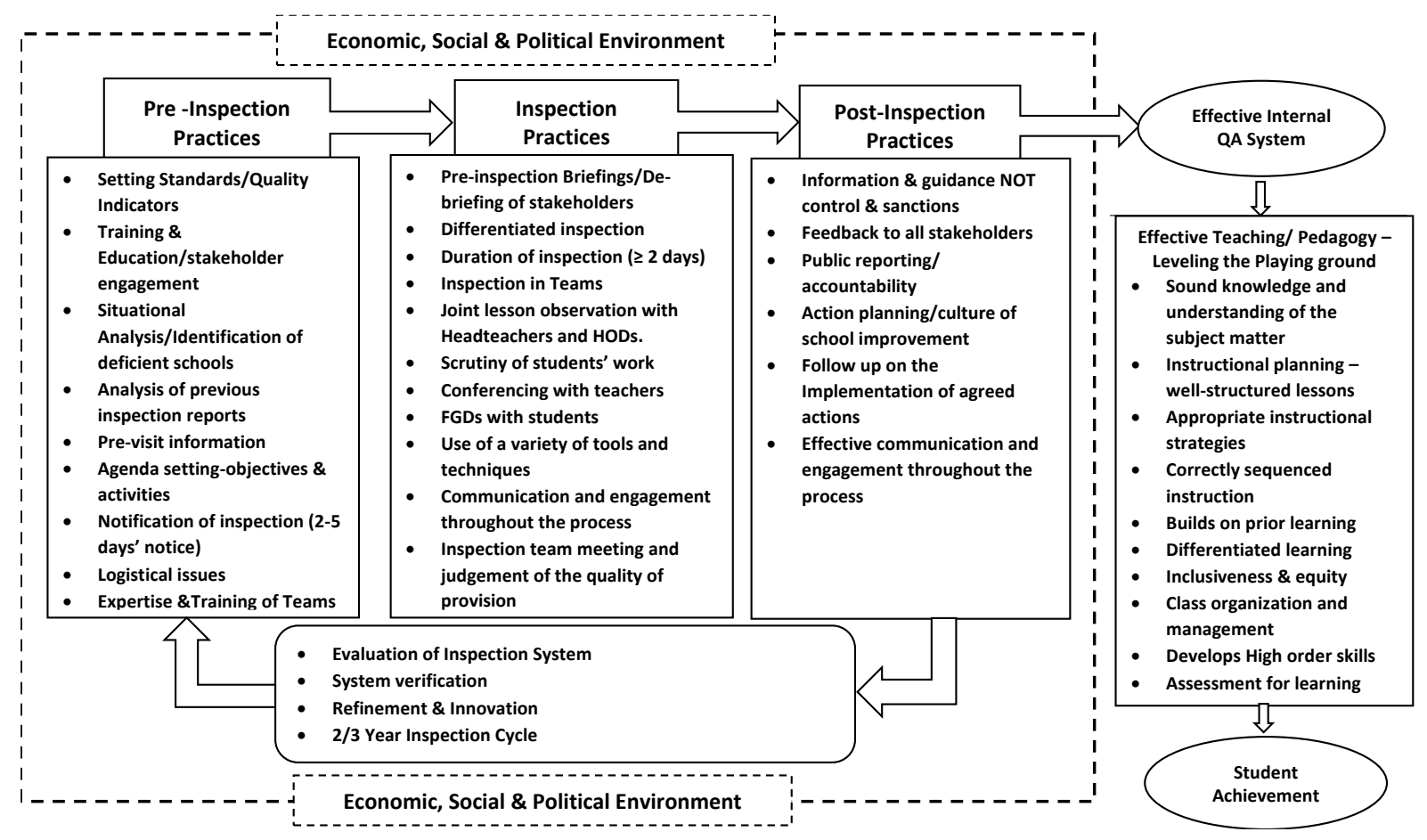

Figure 1. Proposed Model of Effective School Inspection.

The model in Figure 1 provides a framework for an efficient and effective school inspection system. It aims at delivering greater effectiveness, improved efficiency, and reduced administrative burden in the context of budget restrictions. The model assumes that the key measure of success of an effective inspection system is improved internal quality assurance systems and pedagogy. The core of the model is the assumed good practices at the three stages of the inspection process: pre-inspection, inspection and post-inspection. The model incorporates the key elements in each phase that the literature and findings from this study suggest might be critical to an effective and efficient school inspection system.

The pre-inspection phase, which is the period preceding the actual inspection, involves agreement on what good teaching is, conducting risk assessment, notification of schools, and 
assembling resources for inspection. It is essentially a planning phase and also aims at developing rapport with the school staff and therefore has a significant bearing on the success or failure of the inspection.

The second phase, the implementation of the plan or strategy, suggests involvement of all key stakeholders in the inspection process, using differentiated inspection, triangulation of tools and techniques, reasonable duration of inspection, and team meetings and corporate judgements about the quality of education provided by the school.

The third phase is the post-inspection with practices such as providing feedback to individual subject teachers and heads of subjects, final team meeting to arrive at corporate judgement about the school, and briefing of senior managers and the governing bodies. Other presumed good practices include public reporting for accountability purposes, requiring schools to prepare written statements of action that they propose to take in response to the inspection report so as to bring about improvement and following up on the implementation of agreed actions.

Finally, the status of inspection evaluation is one of the key areas upon which the assessment of the effectiveness of the services can be based. The work of inspectors should be monitored and assessed against set standards for quality of judgements, evidence, communication and conduct and the extent of improvement in the system. In addition, all schools should participate in post-inspection survey, the views of which contribute to inspection development. The model outlined here demands time and other resources. If inspection agencies are pressured to undertake too many tasks with limited resources, the quality will be undermined. Because of that, inspection should be targeted at schools and areas where is it most needed.

School inspection does not operate in a vacuum. It is greatly affected by its context, as the bold broken line in Figure 1 suggests. The inspection system is likely to be affected by the current political, social and economic conditions. Although school inspectors cannot control these conditions, they should be aware of them and be in position to at least anticipate them or perhaps attempt to influence them since they will alter the framework within which the inspection system operates.

\section{Acknowledgement}

Danish Fellowship Centre (DFC) through the Building Stronger Universities Project of Gulu University financed this research. Mak-SIDA and THRiVE Project also financed short courses for enhancing research skills of the PhD Candidate.

\section{References}

Ahmad, I., Said, H., Khan, F., \& Ali, A. (2013). Barriers to Effective School Inspection in Pakistan and Way Forward. World Applied Sciences Journal, 24(6), 814-821. https://doi.org/10.5829/idosi.wasj.2013.24.06.1226

Aleesha, M. J. (2012). School Inspection System (No. 276).

Ali, M. A. (1998). Supervision for teacher development: A proposal for Pakistan. Paris: 
IIEP/UNESCO. Retrieved from http://ddp-ext.worldbank.org/EdStats/PAKpub98.pdf

Amin, M. E. (2005). Social science research:Conception, methodology and analysis. Kampala: Makerere University Press.

Balnaves, M., \& Caputi, P. (2001). Introduction to Quantitative Research Methods: An Integrative Approach. SAGE Publications, Inc.

Baxter, R., Hastings, N., Law, A., \& Glass, E. J. . (2014). Evaluation of School Improvement: A Guide to Follow-Through Inspection. Dublin: Department of Education and Skills.

Bolton, R. (2005). Habermas's Theory of Communicative Action and the Theory of Social Capital. Williamstown: Author. https://doi.org/10.1002/crq.106

Brown, M., McNamara, G., O'Hara, J., \& O'Brien, S. (2016). Exploring the changing face of school inspections. Eurasian Journal of Educational Research, 66, 1-26. https://doi.org/10.14689/ejer.2016.66.1

Carron, G., \& De Grauwe, A. (1997). Current Issues in Supervision: a literature review. Trends in School supervision. Paris: UNESCO.

Carron, G., De Grauwe, A., \& Govinda, R. (1998). Supervision and support services in Asia. A comparative analysis. Trends in school supervision (Vol. I). Paris: UNESCO.

Casteel, V., \& Roebuck, M. (2000). The Education Standards Agency: A Report to the Uganda Ministry of Education and Sports. Glasgow: Author.

Cochran, W. G. (1977). Sampling Techniques. New York, Chichester, Brisbane, Toronto, Singapore: John Wiley \& Sons.

Cohen, L., Manion, L., \& Morrison, K. (2007). Research Methods in Education (6th ed.). New York: Routledge. https://doi.org/10.1111/j.1467-8527.2007.00388_4.x

Council of the Inspectors General on Integrity and Efficiency. (2012). Quality Standards for Inspection and Evaluation. Quality Standards for Inspection and Evaluation. Author.

Creswell, J. W. (2009). Research Design: Qualitative, Quantitative, and Mixed Methods Approaches (3rd Editio). Los Angeles, London, New Delhi, Singapore: SAGE.

de Grauwe, A. (2001). School supervision in four African countries. Volume 1: Challenges and reforms (Vol. I). Paris: IIEP/ENESCO.

Education (Pre-Primary, Primary and Post-Primary) Act, 2008. Acts Supplement, 44 UPPC $\S$ (2008). Uganda.

Education Standards Agency. (2006). A Handbook for School Inspectors. Kampala: Education Standards Agency.

Ehren, M. C. M. (2016). Methods and Modalities of Effective School Inspections. (M. C. M. Ehren \& K. M. Merki, Eds.). London: Springer. https://doi.org/10.1007/978-3-319-31003-9

Essaoudi, M., Lotfi, R., Talbi, M., \& Radid, M. (2015). Analysis of Professional Practices 
Inspectors of Education - Training in Morocco. Procedia - Social and Behavioral Sciences, 197, 320-327. https://doi.org/10.1016/j.sbspro.2015.07.144

Fergusson, V. (1998). Supervision for the self-managing school: the New Zealand experience. Trends in School supervision. Paris: UNESCO.

Gichohi, G. W. (2015). Stakeholder involvement in Schools in 21 st Century for Academic Excellence. International Journal of Education and Research, 3(2), 13-22. Retrieved from http://www.ijern.com/journal/2015/February-2015/02.pdf

Government of the Republic of Uganda. (1992). Government White Paper on the Education Policy Review Commission Report: Education for National Integration and Development. Kampala: Government of the Republic of Uganda.

Gray, A. (2014). Supporting school improvement: The role of inspectorates across Europe. Brussels. Retrieved from http://www.sici-inspectorates.eu

Guba, E. G., \& Lincoln, Y. S. (1994). Competing Paradigms in Qualitative Research. In N. K. Denzin \& Y. S. Lincoln (Eds.), Handbook of Qualitative Research (pp. 105-117). Thousand Oaks, London, New Delhi: SAGE Publications, Inc.

Habermas, J. (1984). The Theory of Communicative Action Vo. 1: Reason and Rationalisation of Society (Vol. 1). Boston: Beacon Press.

Habermas, J., \& McCarthy, T. (1987). The Theory of Communicative Action: Vol. 2: Lifeworld and System: A Critique of Functionalist Reason. Contemporary Sociology (Vol. 2). Boston: Beacon Press. https://doi.org/10.2307/2072540

Hammond, M. (2013). The contribution of pragmatism to understanding educational action research: Value and consequences. Educational Action Research, 21(4), 603-618. https://doi.org/10.1080/09650792.2013.832632

Haris, I., Naway, F. A., Pulukadang, W. T., Takeshita, H., \& Ancho, I. V. (2018). School Supervision Practices in the Indonesian Education System; Perspectives and Challenges. Journal Od Social Studies Education Research, 9(2), 366-387.

Hooge, E., Burns, T., \& Wilkoszewski, H. (2012). Looking Beyond Numbers: Stakeholders and Multiple School Accountability.

Hossain, M. (2017). School Inspection Challenges:Evidence from Six Countries. Paris.

Ige, A. M. (2012). The Challenges Facing Schools' Inspection Amid Universal Basic Education (UBE) Implementation In Nigeria. International Journal of Learning and Development, 2(5), 203-214. https://doi.org/10.5296/ijld.v2i5.1986

IIEP-Unesco. (2007). Roles and functions of supervisors. Serie "Reforming School Supervision for Quality Improvement." Paris: UNESCO. Retrieved from http://www.iiep.unesco.org

Janssens, F. J. G. (2011). An Evaluation of the Impact of the Publication of School Performance Indicators in the Netherlands. International Journal of Educational Policies, 
$5(2), 55-73$.

Kalolo, J. F. (2015). The Drive towards Application of Pragmatic Perspective in Educational Research: Opportunities and Challenges. Journal of Studies in Education, 5(1), 150-171. https://doi.org/10.5296/jse.v5i1.7145

Kivunja, C., \& Kuyini, A. B. (2017). Understanding and Applying Research Paradigms in Educational Contexts. International Journal of Higher Education, 6(5), 26-41. https://doi.org/10.5430/ijhe.v6n5p26

Lugujjo, E. (2008). A Critique of the Post-Primary Education and Training. Kampala: Author.

Manase, J., \& Habibu, D. A. (2017). Stakeholders 'Perceptions on the Adequacy of External Supervision in Secondary Schools in Chamwino District , Tanzania. International Journal of Innovative Research and Development, 6(10), 157-162.

Miles, M. B., \& Huberman, A. M. (1994). Qualitative data analysis (2nd ed.). Thousand Oaks, London, New Delhi: SAGE Publications, Inc.

Ministry of Education and Sports. (2004). The national report on the development of education in Uganda at the beginning of the 21 st century. Kampala.

Ministry of Education and Sports. (2008). Revised Education Sector Startegic Plan 2007-2015. Kampala: Ministry of Education and Sports.

Ministry of Education and Sports. (2012). How we inspect: A Guide to External Evaluation. Kampala: Ministry of Education and Sports.

Ministry of Education and Sports (MoES). (2000). A Framework for Monitoring and Evaluation of the Education Sector. Kampala: Author.

Ministry of Education and Sports (MoES). (2013). Education Abstract. Kampala: Author.

Ministry of Education and Sports (MoES). (2017). Education Sector Strategic Plan 2017/18 2019/20. Kampala: Ministry of Education and Sports.

Mitrović, L. (1999). New Social Paradigm: Habermas's Theory of Communicative Action. Philosophy and Sociology, 2(6), 217-223. Retrieved from http://www.ceeol.com

Mohanty, B. (2000). School Administration and Supervision. New Delhi: Deep and Deep.

Mokoena, S. (2011). Participative Decision-making: Perceptions of School Stakeholders in South Africa. Journal of Social Sciences, 29(2), 119-131. https://doi.org/10.1080/09718923.2011.11892962

Moswela, B. (2010). Instructional supervision in Botswana secondary schools: An investigation. Educational Management Administration and Leadership, 38(1), 71-87. https://doi.org/10.1177/1741143209351811

National Planning Authority. (2010). National Development Plan 2010/11-2014/15. Kampala: National Planning Authority. 
Ofsted. (2013a). School inspection handbook. Ofsted. Manchester: Ofsted. https://doi.org/10.4324/9780203416242_chapter_2

Ofsted. (2013b). The framework for school inspection. Ofsted. https://doi.org/10.4324/9780203416242_chapter_2

Ofsted. (2017). "Do two inspectors inspecting the same school make consistent decisions?" Manchester:Author.

Panigrahi, M. R. (2012). Implementation of Instructional Supervision in Secondary School : Approaches , Prospects and Problems. Science, Technology and Art Research Journal, 1(3), 59-67.

Penninckx, M., Vanhoof, J., De Maeyer, S., \& Van Petegem, P. (2015). Effects and side effects of Flemish school inspection. Educational Management Administration and Leadership, 1-17. https://doi.org/10.1177/1741143215570305

Pradhan, M., Suryadarma, D., Beatty, A., Wong, M., Alisjahbana, A., Gaduh, A., \& Artha, R. P. (2012). Improving Educational Quality through Enhancing Community Participation: Results from a Randomized Field Experiement in Indonesia. Author.

Republic of Uganda. (2013). Uganda Vision 2040: Accelerating Uganda's Socioeconomic Transformation. Kampala: National Planning Authority. https://doi.org/10.1007/s11947-009-0181-3

Saldana, J. (2009). The Coding Manual for Qualitative Researchers - Johnny Saldana Google Books. SAGE Publications Ltd. London, Thousand Oaks, New Delhi: SAGE Publications, Inc. https://doi.org/10.1017/CBO9781107415324.004

Saunders, M., Lewis, P., \& Thornhill, A. (2007). Research Methods for Business Students (Fourth Edi). Harlow, London, New York, Boston: Pearson Education Limited. https://doi.org/978-0273701484

Scanlon, M. (2001). the Impact of Ofsted Inspections : the Experience of Special Measures Schools. Readership:Primary, Secondary, Special, (25), 1-4.

Shannon-Baker, P. (2016). Making Paradigms Meaningful in Mixed Methods Research. Journal of Mixed Methods Research, 10(4), 319-334. https://doi.org/10.1177/1558689815575861

Singhal, R. P., Bhagia, N. M., Kalpande, V. A., \& Nair, T. D. K. (1986). School Inspection System: A Modern Approach. New Delhi: VIKAS.

Tanah, R. N. (2011). Appraisal of the Inspection of Secondary Schools in the North West Region of Cameroon. University of Nigeria, Nkukka. https://doi.org/10.1080/01402390.2011.569130

Teddlie, C., \& Tashakkori, A. (2015). Overview of Contemporary Issues in Mixed Methods Research. In SAGE Handbook of Mixed Methods in Social \& Behavioral Research (2nd ed., pp. 1-42). https://doi.org/10.4135/9781506335193.n1 


\section{Macrothink}

United Nations. (2015). The Millennium Development Goals Report 2010. United Nations. New York: United Nations. https://doi.org/10.1177/1757975909358250

Ward, M., Penny, A., \& Read, T. (2006). Education Reform in Uganda 1997 to 2004 : Reflections on Policy, Partnerships, Strategy Implementation. London: DFID.

Wiersma, W., \& Jurs, S. G. (2005). Research Methods in Education: An Introduction (8th ed.). Boston: Allyn and Bacon.

Wilcox, B. (2000). Making school inspection visits more effective: The English experience. Paris: UNESCO.

Winkler, D., Sondergaard, L., Nannyonjo, H., Habyarimana, J., \& Shkaratan, M. (2008). The Efficiency of Public Education in Uganda. Kampala.

\section{Copyright Disclaimer}

Copyright reserved by the author(s).

This article is an open-access article distributed under the terms and conditions of the Creative Commons Attribution license (http://creativecommons.org/licenses/by/3.0/). 